\title{
Parliamentarianism: concept, signs, and problems of development in Russia
}

El parlamentarismo: concepto, signos y problemas de desarrollo en Rusia

Lyudmila Konovalova ${ }^{1}$

Altai State University - Russia

vaskova82@mail.ru

\begin{abstract}
The article analyzes various ideas about the concept and features of parliamentarism. On the basis of the generalization of the legal literature, the following set of features of parliamentarism is denoted: 1) rule of law; 2) separation of powers; 3) participation of the parliament in bodies of executive, judicial and other branches of power; 4) accountability of the executive power to the parliament; 5) multiparty nature, the right to political opposition and ensuring the connection of the population with the state mechanism; 6) special status of the deputy with a free mandate and responsibility before the law; 7) independence of the parliament; 8) special status of the deputy with a free mandate and responsibility before the law. The concept of parliamentarism proposed to counteract state bureaucratization. We connected the idea of parliamentarism with the possibility of mitigating authoritarian tendencies in Russian political system.
\end{abstract}

Keywords: Parliamentarianism, MP, separation of powers, rule of law, multiparty politics.

\section{RESUMEN}

El artículo analiza varias ideas sobre el concepto y las características del parlamentarismo. Sobre la base de la generalización de la literatura jurídica, se denota el siguiente conjunto de características del parlamentarismo: 1) estado de derecho; 2) separación de poderes; 3) participación del parlamento en órganos de poder ejecutivo, judicial y otros poderes; 4) responsabilidad del poder ejecutivo ante el parlamento; 5) naturaleza multipartidista, el derecho a la oposición política y asegurar la conexión de la población con el mecanismo estatal; 6) estatus especial del diputado con libre mandato y responsabilidad ante la ley; 7) independencia del parlamento; 8) estatus especial del diputado con libre mandato y responsabilidad ante la ley. El concepto de parlamentarismo propuesto para contrarrestar la burocratización del estado. Conectamos la idea del parlamentarismo con la posibilidad de mitigar las tendencias autoritarias en el sistema político ruso.

Palabras clave: parlamentarismo, parlamentario, separación de poderes, estado de derecho, política multipartidista. 


\section{INTRODUCTION}

In the context of the recent strengthening of authoritarian principles of the Russian statehood, various scientific concepts are of interest, which offer directions of decentralization of administrative processes. Accordingly, within the framework of the constitutional law of Russia a somewhat forgotten theory of parliamentarism is being reanimated. During the Soviet period, bourgeois parliamentarism was considered in detail from a critical point of view. In the 90s, the idea of parliamentarism was supported, but later gave way to the concept of a strong state, the "single vertical of power". At the same time, the idea of parliamentarism is designed to resist the arbitrariness of the executive branch of power, and may be quite effective in balancing the power levers of modern Russia.

The chosen topic of the study is relevant not only for Russia, but also for the international community as a whole. In recent years, there have been works by foreign authors drawing attention to the excessive strengthening of the executive branch of government and the devaluation of democratic procedures. The point is that modern streamlined parliamentarianism is in decline due to the dominance of corporatism, party rule and strengthening of the executive branch. The weakening of parliamentarianism is determined by two opposing trends: fragmentation of party representation on the one hand, and usurpation of power by the parliamentary majority, the dominant factions, on the other. The general consequence is the replacement of the substantial legislative activity with the partyfractionation "machine", the loss of executive power in the legislative process, the delegation of legislative powers to the government, the growth of bureaucracy, populism (Sajo, Uitz, 2017).

The term "parliamentarism" itself is found in the works of pre-revolutionary authors, in the works of Soviet scientists, in modern jurisprudence, and in foreign literature. However, no universal definition of this concept has yet been developed. There are disputes about what levers can be used to ensure a balance of public power levers, as well as the reality and efficiency of the implementation of parliamentary powers. The question is raised about the effectiveness of modern lawmaking.

The purpose of the work is to conduct a comprehensive study of the category of "parliamentarism" and to review the main approaches to the perception of its features. Accordingly, along with the disclosure of different points of view on the understanding of parliamentarianism and its basic features, the aim was to propose its integration perception and authorial approach in outlining the specific features of parliamentarianism. One of the tasks was to develop general recommendations for improving parliamentarism in Russia.

\section{Methods}

The article was written using the formal legal method, the method of comparative jurisprudence, hermeneutics, synergetics and dialectics. The international acts and the legislation of the various countries, law-enforcement practice concerning questions of parliamentarism have been analyzed. Works of Russian and foreign authors in the sphere of public state law were used.

\section{DEVELOPMENT}

\section{Results and discussions}

Quite often, parliamentarism is defined as a special system of organization of state power, structurally and functionally based on the principles of separation of powers, the rule of law under the leading role of parliament in order to establish and develop relations of social justice and law and order (Large, 2004; Modern, 1999).

A vulnerability in such definitions is the reference to the "lead" role of parliament, which may be associated either with the parliamentary form of government or with some dominance of parliament over other branches of government.

Parliamentarism is generally defined through the categories of "regime" (Levin, 1960; Mogunova, 2008), "forms of public management of society" (Gabrichidze et al., 2003), "parliamentary form of government" (Arzamaskin, 2006; Von Sydow, 1997), "political system" (Rybkin, 1995), "system of public management of society" (Mishin, 1996), "some scale of social values" (Mironov, 1996), "political institution" (Alizoda, 2012), "state system" (Baglai, 2004), "principles" (Kramskoy, 2010), "a set of theoretical concepts, legislative acts, legal relations" (Rumyantseva, Gulyaeva, 2006); "a set of ideas and experience of representative implementation of the power of the people through the parliament" (Bogdanova, 2003); "socio-political and ideological movement" (Onishko, 1999). However, perhaps the most common option is to refer to parliamentarianism as a "special system of organizing public power" (Parliamentary, 1999; Kramskoy, 2013).

It is obvious that in the cases under consideration the authors speak about completely different sides or positions of parliamentarism. Without claiming to be absolutely correct, it is possible to consider parliamentarianism in constitutional law in four ways: 1) as a theoretical concept, which includes scientific developments on what parliamentarism should be like ideally; 2) as a special system of organization of public power, reflecting the essential 
role of parliament in a particular state in practice; 3) as a legal institution, i.e. a set of rules of law regulating the high status of parliament in the state (and in this sense is consonant with parliamentary law); 4) as a principle of the structure of the state ("hidden" constitutional principle).

At the same time, the second semantic meaning of parliamentarism as a special system of organization of state power is central, since other manifestations of parliamentarism are derived from it. It is the peculiarities of the organization of public power that are considered by scientists when studying parliamentarism; it is the peculiarities of the organization of public power that form the basis for the legal regulation of parliamentarism in a particular country, and it is they who act as a "hidden" constitutional principle.

In order to define parliamentarianism as a special organization of state power, it is important to identify its qualifying features. In this regard, there are many points of view in legal science. At the same time, different authors may indicate the characteristics, properties, principles, and conditions of parliamentarism, which allow to characterize this legal phenomenon in more detail.

In particular, according to V.A. Shekhovtsov, the features of parliamentarism are the separation of powers, multiparty politics, and a free mandate of a deputy (Shekhovtsov, 2002). I.M. Stepanov considers the following to be signs of parliamentarism: separation of powers, rule of law, a fully functioning parliament with law making and control prerogatives, multiparty system, political and ideological diversity, recognition of rights and freedoms of citizens (Parliamentary, 1999). R.M. Romanov attributes to the peculiarities of the phenomenon under consideration the powers of the parliament in terms of lawmaking, election of the government, control over its activities (Romanov, 1998).

In V.E. Usanov's opinion, the content of the concept of parliamentarism is based on the following principles: the independence of parliament from the crown power; the presence of a system of checks and balances; the bicameral nature of the federal and polyethnic state; the maximum approximation of the parliament of the republic (monarchy) to the rule of law (Usanov, 2006). A.A. Amiantov notes the four constitutional principles of parliamentarism, which guarantee its development in the modern state - the power of the people, the separation of powers, ideological and political diversity, as well as federalism (Amiantov, 2007).

According to A.V. Vystropova, the content of the concept of "parliamentarism" includes such elements as the rights and freedoms of man and citizen, the theory and practice of separation of powers, the idea of the rule of law, the concept of formation of civil society (Vystropova, 1999).

There are many other opinions regarding the designation of the peculiarities of parliamentarism, predetermined by differences in the very understanding of the term. Nevertheless, on the basis of generalizations of various literature, it seems logical to designate qualifying features of parliamentarism from the point of view of its separation from the elements of the form of the state and the inadmissibility of literal understanding of the "rule of parliament". Therefore, in our view, the following qualifying features distinguish parliamentarianism as a special organization of public power:

\section{Rule of law.}

This feature of parliamentarianism is also one of the fundamental principles of modern statehood. It presupposes mandatory adherence to laws as normative legal acts adopted by the parliament (or because of direct expression of the will of the people) on the most important issues of the life of society and the state, as well as having priority over all by-laws. It is assumed that the law should be legal, that is, fair, correct, objectively necessary (State, 2007).

This ideal model, with its apparent simplicity, is difficult to implement in practice. The fact is that, firstly, in the modern state in the conditions of expansion and complication of the spheres of legal regulation, extensive law-making of executive authorities and recognition of the phenomenon of judicial law-making the difference between the law and the by-law, the "primary" and "secondary" legislator, the normative legal act and the act of interpretation of law are less and less obvious (Filippova, 2009).

In practice, this gives ground for different legal interpretations and political manipulations in specific life situations. Still, legal fixation and aspiration to implement the principle of the rule of law by different participants of legal relations allows states to develop in a fairer, more humanistic direction.

Secondly, the principle under consideration may be interpreted differently in different states, taking into account the specifics of the history of legal institutions. For example, in Eastern European states, the principle of the Supremacy of Statute Law, i.e. the rule of law, is primarily concerned. Since 2010, China has been actively developing the principle of "governance under the rule of law", which implies an emphasis on individualization within the patriarchal model of statehood (Serov, 2007). The Anglo-Saxon "rule of law" and the German- 
Romanesque "rechtsstaat", "etat de Droit", "estado de derecho" are not just different linguistic expressions of the same phenomenon, denoted in the Russian translation as "rule of law", but different scientific concepts (Marchenko, 2009).

In Anglo-Saxon doctrine, the term "rule of law" is based on centuries-old judicial practice (Zorkin, 2015). In the studies of Western authors it is emphasized that the traditional Anglo-Saxon interpretation of the rule of law principle is reduced to the establishment of such a legal order, in which the court, and not the legislator would have the power to finally solve the question of what is law and what is not such (Allan, 2001; Dicey, 1992; Goldford, 2005). In the countries of the Romano-Germanic legal system, the idea of the rule of law was first theoretically embodied in the concept of the rule of law ("rechtsstaat") and only later was it implemented in practice.

This model was initially oriented to the legislative activity of the parliament and appeals to the legislative order of solving fundamental issues of law (Sampbell, 1996). However, to date, differences in the understanding of the "rule of law" in these legal systems are leveled out, since the process of convergence of the system of sources of law is underway in the respective countries (Marchenko, 2008), as well as some international perception of this phenomenon is formed.

For example, the World Justice Project, an international non-governmental organization, has developed a system of indicators for calculating the rule of law index for different countries of the world and has been applied in practice for several years now. These indicators include the degree of limitation of the powers of government institutions, the level of corruption, order and security, guarantees for the protection of fundamental rights, transparency of government institutions, compliance with the law, and the quality of justice (Zorkin, 2015). The Copenhagen Conference on Security and Cooperation in Europe (CSCE) in its Final Document expressed the will of the 35 CSCE member states to recognize that the rule of law means much more than just formal legality; it also means justice based on the recognition and full acceptance of the supreme value of the human person, guaranteed by the institutions that provide the framework for its fullest expression (Moore, 1992).

Today, the principle of the rule of law and the rule of law is often supplemented by the relatively new term "constitutionalism", which in general means, first of all, the very existence of the constitution and its active influence on the political life of the country, the rule of law and the defining role of the constitution (written or unwritten) as a basic law in the system of existing legislation, the mediated political relations with constitutional legal norms, constitutional recognition of the rights and freedoms of the individual, the legal nature of the relationship between the citizen and the citizen.

The institution of constitutional justice introduces a new dimension to the rule of law and the constitution. At the beginning of the twentieth century, this institution existed only in a few countries, and a significant political role played only in the United States. Now it is fixed by all constitutions of the second and subsequent "generations" adopted after the Second World War.

At first glance, it may seem that constitutional justice undermines the traditional principle of the rule of law, since the hierarchy of state bodies has one (usually the judiciary) that is "higher" than the representative body parliament - and is empowered to check the legislative acts of parliament. For this, bourgeois countries have been criticized by the Soviet science of state law (Modern, 1985). Today, in the legal literature of different countries the question of the limits of interference of constitutional justice in the prerogatives of the legislator is widely discussed. Various theories of "judicial self-limitation" and "judicial activism" are being developed, individual cases of active interference of constitutional courts of some countries in political decision-making are analyzed (Crowe, 2007; Abraham, 1993; Belknap, 1999; Aloisi, Meernik, 2017; Waldron, 1998).

However, by the present time the Russian jurisprudence has accepted the arguments of foreign scientists substantiating the expediency of the existence of the body of constitutional control, which does not oppose the will of the people, because it is entrusted with the function of protection of the constitution, which is the most solemn and profound expression of the will of the people, from possible encroachments from the Parliament in case of disrespect for the Fundamental Law (Bourdon et al., 1980). Moreover, Russian scientists have introduced the category of "judicial constitutionalism" as an adaptation of the theory of the rule of law to the realities and positive meaning of constitutional justice, which implies judicial protection of constitutional prescriptions, as well as the formation of "living" constitutionalism under the influence of acts of the constitutional court (Bondar, 2013).

This approach is in line with the modern pan-European ideas about the supremacy of the constitution. Thus, the general report of the XIV Congress of the Conference of European Constitutional Courts, held in Vilnius on June 3-6, 2008, states: "Only an active position of the constitutional court ensures a real, and not an expected, implementation of the principle of constitutional supremacy" (Constitutional Justice. Bulletin of the Conference of Constitutional Review Bodies of Young Democracies. Yerevan, 2008. Issue. 2-3. . 110-111). 
2. Separation of powers with clear and effective powers of parliament.

It is obvious that parliamentarianism presupposes the efficiency of the parliament's implementation of its competence, i.e. rights and duties (powers) in certain spheres of life of the society and the state. At the same time, the modern state is characterized by legislative or even constitutional regulation of the powers of the parliament. Therefore, it is customary in legal science to classify parliaments in the form of fixing their powers on those with unlimited competence, absolutely limited competence and relatively limited competence (Constitutional, 2000).

In order to compare the content of the competence of parliaments, a more consolidated division of parliamentary powers into functions (main areas of activity) of parliament is used. Traditionally, the functions of parliament are referred to as legislative, representative and oversight functions. However, various authors additionally highlight the constituent, stabilizing, financial, foreign policy, administrative and other functions of parliament (Kotelevskaya, 1997; Kolobov et al., 1991). In this regard, it is noteworthy that there is often a scientific dispute about the allocation of the main function of the parliament. For example, Russian scientists usually refer to a representative or legislative function as such. In English legal doctrine, the "palm of supremacy" is usually given a control function. German authors prioritize the function of forming the state will in conditions of constant competition between parliament and other supreme authorities (Russian, 2006).

However, the legislative regulation of the competence of parliament is not the only factor that determines the efficiency of the exercise of its powers in practice. For example, the presence of legally defined powers of parliaments in fascist Germany or in many post-Soviet countries of Eastern Europe has not yet predetermined a significant role of representative institutions in reality. What matters is how well the powers of parliament fit into the system of separation of powers and allow it to influence other institutions of power.

The theory of separation of powers developed by J. Locke and S. L. Montesquieu in the context of the struggle of the bourgeoisie against feudal domination is, on the one hand, a necessary attribute of democracy and parliamentarism, and, on the other hand, a stumbling block in numerous scientific discussions

First, the number of authorities is being actively discussed. If the classical variant of the concept of separation of powers presupposes the separation of legislative, executive and judicial powers, then at present this list is proposed to be supplemented by the constituent, electoral, informational, party, presidential, controlling and even bureaucratic powers (Sedegov, 2009; Ebseev, 2014). As a follow-up to this approach, some constitutions either provide for a greater number of authorities or indirectly enshrine the principle of separation of powers, removing the question of the number of its branches. However, it seems that the new branches of power are secondary to the traditional "shamrock", since it is the new branch that lays down the basic mechanisms for preventing arbitrariness and is a means of combating the abuse of power.

Secondly, in the modern state, the power mechanisms are quite complex and imply a certain interweaving of powers with a clear deviation from the classical postulates of the theory of separation of powers. In this connection, the textbook phrase of K. Hesse that the separation of powers "is not carried out anywhere in its purest form" became a textbook one (Hesse, 1981). Therefore, a new interpretation of the principle in question through the prism of division of functions (forms of public power activity) becomes very popular in the legal literature (Maunz, 1980; Problems, 1999; Chirkin, 1990).

But it seems that this approach distorts the essence of the theory and shifts the emphasis from the main to the secondary. Implementation of the principle of separation of powers implies separation not only of functions, but also of power centers, which does not violate the unity of state power, which should be understood as the unity of strategic goals and directions of activity of all state bodies.

Third, the disputes over the designation of the main branch of government among the three branches of government continue unabated. It is well known that J. Locke, when developing the theory of separation of powers, proceeded from the leading role of the legislature (Locke,1988). The doctrine of "the supremacy (sovereignty) of parliament" is still officially recognized in Great Britain (Marchenko, 2008; Bagehot, 1976; Marshall, 1980). Many Russian scholars link the institution of parliamentarism to the rule of law or the leading role of parliament. At the same time, legal doctrine is saturated with theories about the supremacy of executive power (ministerialism, "cabinet supremacy" or even presidentialism) (Mishin, 2008; Egorov, 1987).

There are also theories of the balance of powers (Mogunova, 2001).

Nevertheless, it seems that it is groundless to speak about the supremacy or leading role of the parliament in the system of separation of powers. Such theories represent a kind of legal fiction. For example, in the same United Kingdom, an elevated attitude towards parliament is combined with a parliamentary form of government, the 
downside of which is the strengthening of the bureaucratic apparatus. In this regard, the concept of "ministerialism" has a double meaning in constitutional law. On the one hand, it means an integral component of parliamentarism (in the sense of parliamentary governance), when the role of the Cabinet of Ministers actually increases with the formal legal dependence of the government on parliament.

On the other hand, ministerialism is perceived as an objective exaltation of executive power in all states in the form of ministries, departments, presidents, and so-called "bureaucracy". The primacy of executive power is conditioned by its inherent features in the form of professionalism, deep knowledge of information, coercion, management of all state resources, and efficiency.

Therefore, parliamentarism in the meaning we understand implies not the supremacy of parliament, but the presence of a real possibility of other branches of power to restrain the arbitrariness of executive power, as well as the real powers of parliament to influence other bodies of power, and, first of all, the executive power.

Fourth, the current perception of the principle under consideration is related not so much to the separation of powers as to their interaction. This interaction with the easy hand of American constitutionalists is usually called a "system of checks and balances" (Krylov, 1998). The difficulty lies in the fact that there is no universal way of distributing the powers of state bodies, symbolizing the three branches of power. Each country has to regulate the relations between the authorities in its own way, taking into account historical, cultural, geographical and other features of the state. Therefore, in the conditions of almost universal formal-legal recognition of the principle of separation of powers, some states manage to find a balance between the interaction of powers, and some - not others. Accordingly, one can say that in some states there is parliamentarianism, while in others there is not.

In our opinion, this does not depend on the legal recognition or denial of the dominance of parliament, but rather on the regulation of the powers of state bodies, taking into account the national peculiarities of the country.

3. Participation of parliament in the formation of executive, judicial and other branches of government.

The election or appointment of parliamentary officials (chairpersons, speakers, heads of committees, etc.) is the natural and inalienable prerogative of parliament. However, in order to ensure the reality of the powers of parliament in the context of the principle of separation of powers, it is necessary for a representative body to participate in the formation of other bodies of power. This participation may vary from one body to another, depending on the national context, and from one body to another, and from one body to another, depending on the way in which it is formed.

In parliamentary republics or monarchies, parliaments vote to approve the appointment of the head of government. The forms of parliamentary participation in government formation are diverse in global practice. Parliaments usually participate in the formation of the judiciary. It is also possible for parliament to participate in the formation of bodies of power that have a controversial status from the standpoint of the theory of separation of powers (prosecutors, commissioners).

Of course, the powers of parliaments to form other bodies of power cannot be idealized due to the influence of interpersonal relations and financial oligarchy on these processes, but even taking into account the "injustice" of individual appointments and the actual predetermined staffing of positions in the system of executive power by the opinion of the head of government, the participation of parliaments in the formation of other bodies of power as a sign of parliamentarianism is of great importance. It is connected with the possibility of the parliament to use political levers of pressure to defend its interests, as well as to prevent the recognition of its decisions as unconstitutional or illegal by the supreme courts due to the political bias of the executive authorities.

\section{Accountability of the executive to the Parliament.}

The abovementioned feature reflects the reality of the Parliament's powers of control over the executive branch of power. It does not refer solely to the forms of accountability of the executive in parliamentary republics or monarchies. Today, the methods of parliamentary control can be very diverse and do not necessarily involve a vote of no confidence in the government (resolutions of censure, appeals, oral and written questions, parliamentary investigations, ombudsmen, chambers of account, audit offices, etc.). The main thing is that parliament, through the institution of control, should have real levers to influence the executive branch.

However, even the existence of legal means of parliamentary control does not in itself predetermine its effectiveness - much depends on political and even psychological factors. In this regard, it is appropriate to quote a vivid statement by the British author A. Sampson: "Usually MPs face the simple fact that neither the government nor public officials want MPs to know what is really going on. And MPs lack the will, knowledge or time to 
complete the investigation. In addition, many MPs doubt whether they should criticize civil servants. In the case of the author of the communication, the Committee considers that the State party's failure to comply with its obligations under the Covenant is a violation of article 14, paragraph 1, of the Covenant, and that the author's failure to comply with its obligations under the Covenant is a violation of article 14, paragraph 1, of the Covenant (Sampson, 1975).

The Committee on Economic, Social and Cultural Rights has also noted the importance of the right to freedom of opinion and expression and the right to freedom of opinion and expression, as well as the right to freedom of opinion and expression. A number of countries even use legal levers to increase opposition influence over the government. For example, according to the 1995 Constitution of Georgia, the majority representation in a parliamentary commission cannot exceed half of the total number of commission members (Parliamentary, 2006). In France, following the adoption of the 1958 Constitution, which limited the number of commissions of inquiry to eight in each chamber, attempts are being made to simplify the procedure for establishing commissions in order to strengthen the mechanism of parliamentary investigations (Fedorova, 2014).

Overall, however, practice shows that the control powers of parliaments are less diverse in presidential republics, although their effectiveness is enhanced by the government's lack of powers to dissolve parliament. In contrast, in parliamentary countries, the extensive oversight powers of parliament are largely neutralized by the government's right to dissolve parliament (Mishin, 1996), as well as by a factor of party affiliation, since the party that formed the government does not benefit from drawing attention to its cabinet. In mixed republics, the effectiveness of parliamentary control depends on the balance of political power and the personality of the head of state.

5. Multiparty politics, the right to political opposition, and ensuring that the population is connected to the state mechanism.

To ensure that Parliament does not become a decorative institution, it must function in an environment of political pluralism and public feedback. This feature is facilitated by the constitutionalization and institutionalization of political parties on the basis of equality and freedom of expression. The influence of political parties on the modern state is so great that it gave rise to the theory of a "party state", the central thesis of which is associated with the formation of the political will of the people through parties and its "mediation" in relations with the state power. The most determined representatives of this theory even recognize parties as organs of the state (Trautmann, 1975; Libertan, 1974). However, the main emphasis of the doctrine of "party state" is made on the need for the existence of opposing political forces, alternative political attitudes.

At the same time, the practice of political parties' activity has shown that these organizations have not only positive functions of political course development, participation in the formation and control over the activity of authorities, national integration, etc., but also have a negative manifestation in the form of defending narrow corporate interests, financial abuse, populism, etc. These negative manifestations of the activities of political parties entail disappointment of citizens in political institutions. On April 17, 2007, the Parliamentary Assembly of the Council of Europe was even forced to appeal to the parties with a call to increase their responsibility before the electorate and not to make unrealizable promises to the electorate (PACE Resolution No. 1546 (2007) of April 17, 2007). "Code of Conduct for Political Parties" // State power and local self-government. 2007.

Formation of the real multi-party system depends on political traditions, balance of social forces, economic conditions and other factors. However, there are legal mechanisms for influencing political parties.

For example, it is known that the majority electoral system contributes to the dominance of large parties and even to the formation of bipartisanship. High barrier creates obstacles to the emergence of opposition currents, while in conditions of instability of the political system, the legal recognition of the right to establish party blocs contributes to the strengthening of parties and the formation of party traditions.

The presidential form of government, rather than the parliamentary form of government, encourages deviations from party discipline in the voting process on the adoption of the law on the It is therefore clear that if a country is to develop parliamentarianism, it is necessary to create the legal conditions for multiparty politics.

The legal methods of supporting the opposition in individual countries are also noteworthy. For example, in the United Kingdom, a number of laws have established the official status of the main opposition party (Her Majesty's Opposition), which gives it the right to receive guaranteed cash payments from the state budget, and its leader - to form a "shadow" cabinet and as the head of the said cabinet to receive wages from the same source of funding. In Canada, since 1970, all parties with 12 to 30 MPs have been paid money to set up research services. In the U.S., the 1970 Reorganization Act established the right to appoint one third of the staff of the staff of the committees to members of the minority party in Congress (Osavelyuk, 2013). At the same time, the impact of the population on the state authorities and pluralism of opinions in politics is ensured not only by the activities of political 
parties, but also by the functioning of public associations, business unions, pressure groups, lobbyists, and the media. Moreover, the practice has shown their direct or indirect connection with political parties. Accordingly, parliamentarianism presupposes democratic rules of legal regulation of their activities. This is particularly true of the media, which are often referred to as the "fourth branch of government" and have even begun to receive constitutional entrenchment in recent years.

It is also characteristic for parliamentarism to have direct forms of influence of the population on the authorities through the institutions of direct democracy. These forms can be varied and used in different ways in different countries. In Switzerland, for example, forms of direct democracy, including referendums, are often used in practice. In Germany, on the contrary, the legal doctrine recognizes only elections as the only expression of direct expression of the will of the people (Sajo, 2011).

However, for the formation of parliamentarianism, it is important to have legal means of expressing public initiatives and grievances. Such legal mechanisms are an important political factor in influencing parliament and other authorities and can protect them from abuse of power.

6. Special status of a deputy with a free mandate and responsibility before the law.

A sign of parliamentarianism is the free mandate of the deputy, as it creates conditions for pluralism of opinion in the parliament, makes the deputy look for channels of interaction with the electorate and prevents excessive pressure on the deputy by political parties, pressure groups and other actors. The free mandate of a deputy is characterized by the consideration of a deputy as a representative of the nation as a whole, not an electoral district, as well as the lack of legal regulation of the penalties, reporting and recall of the deputy. Signs of a mandatory mandate are completely opposite to the properties of a free mandate.

Historically, a mandatory mandate was the first to emerge. It was actively used in the Middle Ages (for example, in the General States of France in the 15th-16th centuries), was used in the period of existence of the Paris Commune in 1871 , and later was accepted by the countries of the socialist camp, sometimes it is used in a truncated form at the level of municipalities and subjects of the federation in democratic countries. At first glance, its use should be more consistent with the interests of voters, because it fixes the legal dependence of the deputy on the will of citizens. However, it cannot be fully implemented due to the conflict between the interests of the constituency, the state and the opinion of the deputy himself.

The negative features of a mandatory mandate are: 1) Facilitating the implementation of "local trends" in the representative body; 2) the complexity of application in the conditions of the content of modern legislation; 3 ) dependence on the political activity of citizens; 4) abuse of voters' personal time.

Moreover, most importantly, the imperative mandate is not consistent with the modern principle of separation of powers. A deputy cannot legally take over the execution of Soviet-type orders related to the allocation of funds (building a school, repairing a road, etc.), because the executive and administrative functions are not within the competence of parliament. Nor can a deputy assume any other obligations, since he or she does not make any important decisions on his or her own, but is a member of a collegial body of power. In such conditions, all structures of recall of a deputy are legally damaging. The history of a deputy's free mandate begins with the victory of the New Age revolutions, when the bourgeoisie began to claim the role of a representative of the entire nation. Today, the absolute majority of democratic states recognizes this type of mandate. It is interesting to note that even the practice of the European Court of Human Rights implicitly recognizes the free mandate of a deputy. In particular, in its decision in the case of Gitanas and others v. Greece of July 1, 1997, the Court noted that states are free enough to establish the status of parliamentarians within their constitutional order, based on the need to "ensure the independence of members of parliament, as well as the free expression of the will of voters" (European Court of Human Rights. Selected decisions.M., 2002. . 2. . 458.).

This expansion of a free mandate is predetermined by its positive features: 1) reflection of the national interests in the policy; 2) provision of the deputies with the possibility of maneuvering and compromises in the changing political conditions; 3) reduction of the danger of direct confrontation in the society; 4) freedom to form opinions and will within the party and faction. At the same time, if this model of relations between a deputy and voters is recognized, there is a danger that deputies will defend the interests of a narrow social group under the guise of public interests.

However, it should be noted that the free mandate of a deputy is in some sense a legal fiction and does not correspond to the really developing relations.

In the modern state, the very situation of political rivalry within the framework of the election campaign makes MPs listen to the demands of citizens, be responsive to their needs (Constitutional, 2003; Grafsky, 1991), to seek 
decision-making (financial aid programs, investments, government contracts, etc.), which are expected of them by voters V.I. Fundamentals (Lafitsky, 1998).

The actual independence of a member of parliament can be called into question not only and not so much by the influence of voters, but also by the influence of political parties, pressure groups (lobbyists), public authorities and local government.

In particular, the party nature of the modern state presupposes that the deputy is bound by party discipline. Of course, it is not of a legal nature, there are no legal sanctions for a deputy for its violation (this is the main difference between the free mandate of a deputy and the mandatory party mandate). However, based on political expediency, the deputy is forced to orientate himself on it (Martinoff, 2002). The degree of political interaction of deputies and parties in the states is not equal. The strongest traditions of subordination of deputies to party discipline exist in Great Britain, Germany, Norway, Sweden, Finland, and the Czech Republic.

At the same time, the positive significance of a free mandate is precisely to create legal mechanisms to counteract the full subordination of a deputy's will to party instructions. Otherwise, a free mandate may develop into a socalled mandatory party mandate, the main feature of which is that it is permissible to deprive a deputy of his or her authority in case of deviation from the party's instructions.

The practice of implementing this relatively new mandate in some countries, such as India since 1966, has shown its negative impact on the development of statehood. It consists in the fact that the introduction of this legal structure turns the parliament into a kind of bureaucratic body, subordinate to the direct instructions of the party leaders, losing the quality of representativeness of the parliament (Cherkasov, 1994). Accordingly, such a body can no longer act as a counterweight to the executive power.

Therefore, constitutional control bodies of different countries, as a rule, recognize the illegality of strict subordination of deputies to party discipline (Germany, Romania, etc.) (Jarass, 2002).

It is also important to note that the free mandate of a deputy as a sign of parliamentarianism does not exclude his responsibility to a representative body. The world experience shows the compatibility of a free mandate with the institution of deprivation of a deputy's mandate by the decision of the parliament as a sanction for nonperformance of deputy's duties.

7. The independence of the judiciary and its interaction with the legislative and executive branches of government to ensure a balance of State and legal order.

The developers of the theory of the separation of powers, J. Locke, S. L. Montesquieu, and A. Hamilton, assigned a very modest place to the judiciary, considering it to be "the weakest of the three", because it does not have the capacity to actively participate in politics, does not enjoy the same public confidence in the elections as the legislature, and does not have the same coercive power as the executive branch (Locke, 1988; Montesquieu, 1955; Hamilton et al., 2009). However, the practice of implementing the principle of separation of powers has disproved this thesis. In a modern state, a strong judiciary is regarded as an inherent feature of the rule of law and parliamentarism (Chirkin, 2001).

The strengthening of judicial functions in the form of constitutional justice has led to the emergence of the theory of the "state of judges". It is noteworthy that the above concept was developed especially deeply in Germany in the depths of the continental legal family, where the role of the court has not been traditionally overestimated. The theory of the "judicial state" presupposes the perception of the court as a guarantor of the implementation of the principle of the legal statehood, as a body that is entrusted to decide what is the right and what does not act as such.

Supporters of this theory questioned the ability of the parliament to perform the functions of the guardian of the right, and saw in the formal law the potential threat to freedom and law (Bachoff, 1959). Similar sentiments were among American lawyers during the period when the Supreme Court was in power. Judge Hughes uttered his famous phrase in 1908: "The Constitution of the United States is what the Court will say about it" (Jacquet, 2002).

At the same time, both denigration and excessive elevation of judicial power do not serve the interests of the state. Judges are still people with their own passions, vices and relationships with other people. World experience shows that there are individual cases of unfair or non-legal decisions. For example, in 1857, the U.S. Supreme Court made the "most shameful" decision in its practice about the unconstitutionality of the law allowing citizenship of blacks (Friedman, 1992). It is known that in the post-war period, the judicial bodies of the United States, Canada, and Australia have a biased attitude towards the so-called "subversive elements" - persons and organizations opposing the ruling regimes (Marchenko, 2008). 
History shows periods of both strengthening and weakening of the role of courts in different countries. However, from the perspective of the theory of parliamentarianism, it is important to ensure the balance and balance of power among other branches of government through constitutional and legal means. This can be done through the legal regulation of the leverage of parliament and other bodies, as well as by ensuring the high and independent standing of the judiciary.

In our opinion, the above-mentioned features characterize the effective execution of powers by the parliament, allow it to provide a stable and internally regulated mechanism of stable development of the state in cooperation with other branches of power.

Speaking of parliamentarianism in legal science, one cannot ignore the often negative attitude of ordinary people towards parliament. Citizens of many countries are outraged by the populist promises of MPs, corruption scandals related to their participation, lack of real responsibility for the adopted acts, parliamentary immunity, etc. Particularly disillusionment with parliamentary institutions is observed in countries that have recently adopted democratic values (Harutyunyan, 2013). For example, in Russia, according to official statistics provided by the All-Russian Center of Public Opinion, about 45-50 percent of the population approve of the activity of the Russian parliament in recent years. However, according to alternative data, this amount does not exceed 26 percent (Polovnev, 2015).

Professional lawyers also point to a number of criticisms of the work of parliaments, even in countries with wellestablished democratic traditions. These include, for example, lobbying in parliament for the interests of narrow social groups, slow parliamentary procedures, unprofessionalism of deputies, delegated lawmaking, the fact that the executive authorities have developed the bulk of draft laws, the use of parliamentary powers to build personal careers, etc.

However, despite all its drawbacks, parliament is still of great value, since it predetermines the existence of discussion in the system of power institutions and assumes the presence of legal mechanisms of influence of the opposition on the political decision-making of the power elite. Other state bodies or institutions of direct information influence on the government apparatus (public chambers, Internet interaction with the population, advisory bodies), which are invented today, are not capable of resisting usurpation of power in one hand.

Therefore, it is obvious that it is necessary to develop and improve the institution of parliamentarism, but it is necessary to take into account both positive and negative manifestations of the activity of parliaments and to avoid both humiliating and excessively elevated position of a representative body in the system of separation of powers.

As far as the Russian Federation is concerned, from the standpoint of the theory of parliamentarism, the question of imbalance in the branches of power deserves attention. In the case of formal democratization of the rules of interaction between the President, the Parliament and the executive authorities, specific legal regulation is structured in such a way as to ensure unconditional primacy in the system of separation of powers of the President of the Russian Federation with the executive authorities actually headed by him.

First, this is ensured through the formation of a pro-presidential majority in the State Duma. The electoral legislation has been changed several times in recent years, adapting to the interests of the so-called "party of power" (Kondrashev, 2012; Chaplygina, 2013). The judicial corps and the leadership of the higher courts are formed under the considerable influence of the President of the Russian Federation. The chairmen of the parliament are actually given their seats at the direction of the President in the course of formal and legal procedures of internal democracy. The new way of forming the Accounting Chamber also presupposes a significant influence of the President.

The system and structure of the executive branch of government depend entirely on the President's will. In terms of relations between the deputy and the electorate, in recent years Russia has seen the introduction of elements of a party's mandatory mandate, since the deputy of the State Duma is deprived of his or her mandate in cases where he or she has not been a member of the relevant faction or has resigned from it on his or her own application. The supervisory powers of the Federal Assembly of the Russian Federation even formally and legally do not extend to the activities of the President of the Russian Federation, and taking into account his party composition do not interest the deputy corps in any real forms of control measures. Such legal regulation allows the President of the Russian Federation and the executive power headed by him to conduct any initiative through the parliament practically without discussion, which raises the question of the effectiveness of the legislative process built in this way.

On the one hand, attempts are being made to justify the existing order by the peculiarity of the Russian statehood, the effectiveness of centralized management in difficult economic and political conditions, and the desire of citizens to live in a stable and strong state. 
On the other hand, professionals are discussing the negative consequences of many reforms, including the restructuring of the education system, the liquidation of the Academy of Sciences, the "incompleteness" of anti-corruption legislation, excessive overstatement of administrative fines, abuse by the state of such non-commercial forms of legal entities as state-owned corporations, state-owned companies, institutions, etc., the depressing mismatch between the powers of local governments and their revenue base, and encroachment of government agencies. Undoubtedly, the current situation is also affected by the impossibility of unambiguous answers to the question of how to assess the effectiveness of the legislative process. The criteria for the effectiveness of law-making in the literature are the enforceability of the act, its consistency with the norms of greater legal force, financial feasibility, compliance with the rules of legal technology, stability of legal regulation, etc. However, it is obvious that many of these criteria are narrowly professional or allow for an evaluation approach. Therefore, even among specialists, there is often no unanimity of opinions regarding the adopted laws or draft laws.

At the same time, it is generally thought that authoritarian tendencies of Russia's development are dangerous. They increase the influence of bureaucracy on the processes of public administration, make the head of state hostage to his personal position or the position of close officials, alienate the population from the state administration, entail a decrease in the legitimacy of government institutions, increase the risk of illegal manifestations of discontent with the policy pursued by society, and depress the economic development.

\section{CONCLUSIONS}

Thus, parliamentarism in the sense we understand is called upon to create mechanisms to counteract usurpation of power by the bureaucracy. Parliamentarism does not imply the supremacy of parliament, but rather the existence of a real possibility for other branches of power to restrain the arbitrariness of the executive branch, as well as the real powers of parliament to influence other bodies of power and, above all, the executive branch.

The question of the signs of parliamentarism remains debatable in legal science. In our opinion, the following qualifying features of parliamentarism should be designated: 1) rule of law; 2) separation of powers with clearly defined and real powers of parliament; 3) participation of parliament in the formation of bodies of executive, judicial and other branches of power; 7) accountability of executive power to parliament; 5) multiparty nature, the right to political opposition and ensuring connection of the population with the state mechanism; 6) special status of a deputy with a free mandate and responsibility before the law; 7) independence of the judiciary.

At the same time, the theory of separation of powers, in our opinion, should not be exaggeratedly reduced to a functional distribution of powers. And the principle of the rule of law in the modern understanding implies the existence of constitutionalism, which determines the high role of the constitution as the main law in the system of existing legislation and the possibility of protecting its prescriptions through the institution of constitutional justice.

The advantage of the concept of parliamentarianism is that it does not focus on parliament as such, but rather on the relationship of all branches of government. This avoids reckless decisions in reforming the institutions of power. For example, the proposals by some authors, who, in an effort to move away from authoritarianism in Russia, recommend strengthening the oversight powers of parliament or enshrining a parliamentary form of government in the Constitution, are obviously one-sided.

Implementing such proposals, we see that in the conditions of expanding the regulatory framework of parliamentary control powers, the actual role of the parliament in the implementation of public policy may decline. According to the experience of foreign countries, it is known that under the parliamentary form of government, parliaments do not strengthen, but, on the contrary, surrender their positions in favor of the executive authorities. In general, the concept of parliamentarism, taking into account the practical experience of Russia and foreign countries, can serve as a direction of democratization of statehood; create obstacles to political and economic stagnation and monopolization of power in one hand.

\section{BIBLIOGRAPHIC REFERENCES}

Abraham, H.J. (1993). The Judicial Process. New York.

Alizoda, Z. (2012). To the question of the concept and features of parliamentarism. Constitutional and municipal law, 5, 34-45.

Allan, T.R.S. (2001). Constitutional Justice: A Liberal Theory of the Rule of Law. Oxford: Oxford University Press.

Aloisi, R., Meernik, J. (2017). Judgment Day. New York.

Amiantov, A.A. (2007). Constitutional principles of parliamentarism. Constitutional and municipal law, 18.

Arzamaskin, N.N. (2006). Transformation of the form of government of the modern Russian state. Vestnik of Bashkir University, 3, 43-55. 
Bachoff, O. (1959). Grundgesetz und Richtermacht. Tuebingen.

Bagehot, W. (1976). The English Constitution. Cambridge University Press.

Baglai, M.V. (2004). Constitutional Law of the Russian Federation.Moscow.

Belknap, M.R. (1999). Constitutional Law as Creative Problem Solving: Could the Warren Court Have Ended the Vietnam War? California Western Law Review, 36(1).

Bogdanova, N.A. (2003). Parliamentary law in the system of the constitutional law. Parliamentary procedures: problems of Russia and foreign experience.Moscow.

Bondar, N.S. (2013). Concept of "living" (judicial) constitutionalism: methodology of research in the light of the practice of constitutional justice. Theory and practice of Russian constitutionalism: a collection of reports of the scientific-practical conference devoted to the 75th anniversary of the birth of academician O.E. Kutafin. Vol. 2. Moscow.

Bourdon, J., Pontier, J.-M., Ricci, J.-Cl. (1980). Driot constitutionel et institutions politique. Economica.

Chaplygina, A.Yu. (2013). Manifestations of political corruption in Russia in the conditions of transformation of the political regime and the crisis of the 90s. State power and local self-government, 1.

Chirkin, V.E. (1990). Separation of powers: social and legal aspects. Soviet state and law, 8.

Chirkin, V.E. (2001). Constitutional Law of Foreign Countries.Moscow.

Constitutional (state) law of foreign countries. (2000). Volumes 1-2. General part. Moscow.

Constitutional justice in Lithuania. (2003). Vilnius.

Crowe, J. (2007). Judicial Activism and Restraint. In Encyclopedia of the Supreme Court. D. Schultz. (Ed.). New York.

Dicey, A. V. (1982). An Introduction to the Study of the Law of the Constitution. Indianapolis: Liberty Fund.

Evseev, B.S. (2014). Constitution, power and freedom in Russia: Experience of the synthetic research. Moscow.

Egorov, S.A. (1987) Modern science of the constitutional law in the USA.Moscow.

Fedorova, Yu.G. (2014). Institute of the Parliamentary Investigation in the Russian Federation.Moscow.

Filippova, N.A. (2009). Representation of the public interests in the federal state: peculiarities of the Russian national model. Ekaterinburg.

Friedman, L. (1992). Introduction to American Law. Moscow.

Gabrichidze, B.N., Eliseev, B.P., Chernyavskiy, A.G. (2003). Constitutional law of modern Russia.Moscow.

Goldford, D.J. (2005). The American Constitution and the Debate Over Originalism. Cambridge University Press.

Grafsky, V.G. (1991). Article by Fowler L.L., McCluire R.D. "Political ambition: who decides to run for Congress? Social sciences abroad. Series 4. State and law, 1.

Hamilton, A., Madison, J., Jay, J. (2009). The Federalist papers. Palgrave Macmillan.

Harutyunyan, A.A. (2013). Constitutionalism: Problems of post-Soviet reality. Moscow.

Hesse, K. (1981). Fundamentals of the constitutional order of the Federal Republic of Germany. Moscow.

Howard, D.A.E. (1992). Constitutionalism. Rule of Law: Collection, Moscow.

Jacquet, J.-P. (2002). Constitutional Law and Political Institutions. Moscow.

Jarass, H.D. (2002). Grundgesetz fuer die Bundesrepublik Deutschland: Kommentar von H.D. Jaras und B. Pieroth, 6. Aufl. Muenchen.

Kolobov, O.A., Kornilov, A.A., Sergun, A.A. (1991). Parliamentarism: foreign experience. Nizhny Novgorod.

Kondrashev, A.A. (2012). Peculiarities of the formation of the Russian political system in the context of the characteristics of the state regime. Constitutional and Municipal Law, 5.

Kotelevskaya, I.V. (1997). Modern Parliament. State and Law, 3.

Kramskoy, V.V. (2010). To a question on definition of the concept "parliamentarism". Constitutional and municipal law, 7, 64-70.

Kramskoy, V.V. (2013). Parliamentaryism and Form of Government: Theoretical, Legal and Methodological Features of the Research. Constitutional and Municipal Law, 9.

Krylov, B.S. (1998). Power sharing: system of checks and balances. Journal of Russian Law, 6. 
Lafitsky, V.I. (1998). Fundamentals of the constitutional order of the USA.Moscow.

Large legal dictionary. (2004). A.Ya. Sukharev, V.E. Krutskikh. (Eds.).Moscow.

Levin, I.D. (1960). Modern bourgeois science of the state law.Moscow.

Libertan, E. (1974). Bundestagsparteien im politischen Machtmechanismus der BRD. Berlin.

Locke, D. (1988). Two treatises on the board. Vol. 3. Moscow: Mysl.

Marchenko, M.N. (2008). Legal Systems of the Modern World.Moscow.

Marchenko, M.N. (2009). State and law in the conditions of globalization.Moscow.

Marshall, G. (1980). Constitutional Theory. Cambridge University Press.

Martinoff, M. (2002). To understand why Parliament no longer works, look at how we pick party leaders. Report Newsmagazine (Alberta Edition), 8, 25. Cherkasov, A.I. (1994). Legal regulation of political parties activity in India (Scientific and analytical review). Social and human sciences. Foreign literature. Series 4. State and law, 4.

Maunz, Th. (1980). Deutsches Staatsrecht. Munchen.

Mironov, O.O. (1996). Origins of the Russian parliamentarism. Representative power, 4-5, 67-75.

Mishin, A.A. (1996). Constitutional (state) law of foreign countries. Moscow.

Modern bourgeois state law. Critical essays. (1985). Main institutions. V. 2. Moscow.

Modern dictionary of foreign words.Moscow, 1999.

Modern Parliament: Theory, World Experience, Russian Practice. (2005). O.N. Bulakov. (Ed.).Moscow.

Mogunova, M.A. (2001). Scandinavian parliamentarism: theory and practice.Moscow.

Mogunova, M.A. (2008). Parliamentarism: concept, essence, principles. Public law research. Yearbook of the Center for Public Law Studies, 3 23-27.

Montesquieu, S. (1955). On the spirit of laws. Selected works.Moscow.

Moore, J.N. (1992). Rule of Law: Overview. Rule of Law. Collection. Moscow.

Onishko, N.V. (1999). Ideological and theoretical foundations of Russian parliamentarism. St. Petersburg.

Osavelyuk, A.M. (2013). Principle of protection of minority rights and the rule of law. In Problems of constitutional development of the Russian Federation: collection of articles dedicated to the 90th anniversary of Prof. B.S. Krylov. V.I. Fadeev. (Ed.).Moscow.

Parliamentary Law of Russia. (1999).Moscow.

Parliamentary law. (2006).Moscow.

Polovnev A.V. (2015). Trust in state institutions: Russia in the context of pan-European trends. Vestnik of Moscow State Linguistic University, 2(713).

Problems of the general theory of law and state. (1999). Moscow.

Romanov, R.M. (1998). Concept and essence of parliamentarism. Social and Political Journal, 4.

Rumyantseva, V.G., Gulyaeva, E.A. (2006). Parliamentarism: problems of scientific comprehension of the concept and practice of institutional implementation. State power and local self-government, 12, 39-47.

Russian Parliamentary Law. (2006). Moscow.

Rybkin, I.P. (1995). Formation and development of parliamentarism in Russia. Thesis of Doctoral Dissertation. Moscow.

Sajo, A. (2011). Constitutional Sentiments. New Haven, CT; L.

Sajo, A., Uitz, R. (2017). The Constitution of Freedom: An Introduction to Legal Constitutionalism. Oxford, 2017.

Sampbell, J. (1996). The Legal Theory of Ethical Positivism. Routledge.

Sampson, A. (1975). New Anatomy of Britain.Moscow.

Sedegov, A.V. (2009). Separation of powers as a criterion of the state form classification. Society and law, 1.

Serov, K.N. (2007). Socio-economic policy of the state and political regime: some problems of interrelation. Legal world, 4.

Shekhovtsov, V.A. (2002). Development of the Russian Parliamentarism. Vladivostok.

State and Law Theory. (2007).Moscow. 
Trautmann, H. (1975). Innerparteiliche Demokratie im Parteienstaat. Berlin.

Usanov V.E. (2006). Parliamentarism in Russia: Constitutional and Legal Basis of Development and Activity. Thesis of Doctoral Dissertation.Moscow.

Von Sydow, B. (1997)l Parlamentarismen i Sverige. Utveckling och utformning till 1945. Stockholm.

Vystropova, A.V. Acts of the Federal Assembly of the Russian Federation. Thesis of Doctoral Dissertation. Saratov.

Waldron, J. (1998). Judicial Review and the Conditions of Democracy. Journal of Political Philosophy, 6, 4.

Zorkin, V.D. (2015). Civilization of law and development of Russia.Moscow. 